\title{
Den surreelle konflikt mellem Kina og Japan
}

Mette Holm

Hvis det ikke var så alvorligt, ville det mest af alt minde om en hanekamp. For hvordan løse en konflikt, som aldrig nogensinde bliver kaldt ved sit rette navn?

Da Kinas daværende leder Mao Zedong i 1972 mødtes med Japans daværende ministerpræsident, Tanaka Kakuei, sagde Den Store Rorgænger: "Vi må udtrykke vor taknemmelighed over for Japan. Hvis Japan ikke havde invaderet Kina, havde vi aldrig opnået samarbejde mellem (Kinas nationalistparti) Kuomintang og Kommunistpartiet. Vi ville aldrig have udviklet os og i sidste ende vundet den politiske magt. Det er ved Japans hjælp, at vi er i stand til at mødes her i Beijing."

Mødet var historisk. Det var "normaliseringen" af forholdet mellem Kina og Japan efter det kejserlige Kinas ydmygende nederlag til Japan i 1895 med afståelsen af Taiwan til følge, invasionen i 1930' erne og Den Anden Verdenskrig. Det var led i Mao Zedong og ministerpræsident og udenrigsminister Zhou Enlais nye strategi med at melde sig ind $i$ verden efter over 20 års isolation (når man ser bort fra Folkerepublikkens første tiår med nær kontakt til Sovjetunionen). 1972 var også året, da Kina oprettede diplomatiske forbindelser til USA og indtog Kinas sæde i FN, som ellers havde været besat af Taiwans Kuomintang.

Tanaka skal have svaret sin vært: "Japan skabte mange problemer for Kina ved at invadere landet."

Hvorpå Mao Zedong sagde: "Hvis Japan ikke havde invaderet Kina, ville Kinas Kommunistparti ikke have sejret; derudover ville vi to aldrig have mødtes i dag. Sådan er historiens dialektik."

Ordvekslingen er gengivet i de minutiøse interne kinesiske rapporter fra mødet og oversat af professor 
Geremie Barmé fra Australiens nationale Universitet.

\section{Voldelige demonstrationer}

I begyndelsen af april demonstrerede kinesere i titusindvis mod japanernes seneste genoptryk af historiebøger, der går meget let hen over Japans uhyrlige ugerninger i Kina under Den Anden Verdenskrig; de brændte det japanske flag, forrettede skader på Japans ambassade i Beijing og generalkonsulater i Shanghai og andre byer, og de stormede japanske stormagasiner og fabrikker. Myndighederne, der jo ellers nok kan underdreje den kinesiske befolkning, billigede de voldelige demonstrationer. Kinas udenrigsminister, Li Zhaoxing, sagde, at Japan burde "se sig i historiens spejl og rette blikket mod fremtiden." Kun på den måde kan de to lande leve i fredelig sameksistens, mener udenrigsministeren.

Som så ofte før udløstes en eksplosiv frustration hos kineserne. Den umiddelbare årsag var - som i 2001 og så mange gange tidligere - at Japans historiebøger springer let hen over japanernes uhyrligheder i Kina i 1930'erne og 40'erne.

De nye historiebøger er i store træk et genoptryk af dem fra 2001. De kinesiske myndigheder mere end opmuntrede til demonstrationerne. De kørte demonstranter til demonstrationerne i busser og reagerede ikke på deres ødelæggelse af japansk ejendom og interesser.

Den efterfølgende uge var magthaverne blevet nervøse og smækkede låg på. Fra at have opmuntret til balladen og afholdt sig fra at gribe ind, begyndte aviserne at advare om "sorte hænder" bag de Japan-fjendtlige handlinger. Sorte hænder er de kinesiske myndigheders betegnelse for bagmænd i sammensværgelser $\mathrm{fx}$ under de store demonstrationer mod Kommunistparti og regering $\mathrm{i}$ 1989.

Den amerikansk baserede kinesiske dissidentorganisation Human Rights in China beretter om mindst seks, der blev anholdt for deres medvirken i demonstrationerne i slutningen af april, efter at myndighederne havde fået kolde fødder.

Den moderne teknologi blev også taget i brug; i tiden omkring Arbejdernes Internationale Kampdag, 1. maj, og 4. maj, som er årsdagen for Kinas første store patriotiske protestbevægelse, der blev knust 4. maj 1919, sendte hovedstadens mobiltelefonselskaber sms'er til alle brugere med besked om, at "Beijings Bureau for den offentlige Sikkerhed vil gerne minde om følgende: stol ikke på rygter, spred ikke rygter, udtryk din patriotiske glød på rationelle måder. Deltag ikke i ulovlige demonstrationer - Wangtong Telekommunikation ønsker dig en glædelig arbejderdag."

Ikke unaturligt krævede Japan undskyldning for ødelæggelserne under de voldsomme demonstratio- 
ner. Kina har halvhjertet beklaget og så godt som kun fortalt om det $\mathrm{i}$ den engelsksprogede presse, der er rettet mod udlændinge.

I maj rejste en af Kinas fremmeste diplomater og forhandlere til Japan. Viceministerpræsident, politbureaumedlem og sundhedsminister Wu Yi har tidligere klaret Kinas vanskeligste handelskriser og -forhandlinger. Det var også hende, der blev sat til at redde, hvad reddes kunne, da Kina i flere måneder havde forsøgt at skjule SARS.

Besøget skulle være et symbolsk og diplomatisk forsøg på at genoprette lidt af forholdet. Ganske vist havde ministerpræsident Junichiro Koizumi inviteret sin kollega Wen Jiabao, men Wen blev hjemme som tegn på, at vist er Japan vigtig, men mishaget er stadig for stort. Så langt så godt. Men midt i det hele afbrød Wu Yi sit besøg og vendte hjem til Beijing uden anden forklaring end, at "pludseligt opståede interne anliggender" fordrede hendes tilstedeværelse. Heller ikke Wu Yis afbrudte rejse nåede de kinesiske medier.

Uofficielt hed det sig, at hun rejste hjem, fordi Koizumi end ikke ville tale om at aflyse sit årlige besøg på Yasukuni - den helligdom, hvor japanerne mindes deres faldne i Den Anden Verdenskrig.

Det kan undre, at netop Kina, der har et overordentligt frit forhold til historien, hænger sig så vældigt i Japans fortolkning af deres frygtelige fælles fortid. Hvis Kina selv havde gjort op med alle de uhyrlige kampagner, der i Folkerepublikkens første 30-40 år kostede millioner af mennesker livet, havde kravet klinget renere.

\section{Kinesisk dobbeltmoral}

Men intet tyder på, at Kommunistpartiet og regeringen har planer om en regulær historiefordøjelse, som den de kræver af Japan. Denne modsigelse blev bragt op få dage før 16-året for massakrerne i Beijing og andre store byer mod demonstranter i 1989.

En gruppe, bestående af 125 nære slægtninge til unge demonstranter, der forsvandt 4. juni 1989, opfordrede til, at de ansvarlige for massakrerne bliver stillet til ansvar, og at ofrene og deres efterladte får oprejsning. I et åbent brev til præsident $\mathrm{Hu}$ Jintao kaldte gruppen Kinas regerings tilbagevendende kritik af Japans regering for ikke at ville give en formel undskyldning for krigstidens uhyrligheder dobbeltmoralsk.

De efterladte opfordrer Kinas regering til at handle i overensstemmelse med sin egen politik "mennesker først" og "harmonisk samfund;" de efterladte skriver, at de kinesiske myndigheder var lige så brutale over for ubevæbnede demonstranter, som den japanske hær var det over for hjælpeløse civile under den kinesiskjapanske krig.

Man skal nu ikke regne med, at magthaverne i Kina vil gøre op med 
den officielle fortolkning af begivenhederne for 16 år siden. For den sags skyld er de japanske historiebøger da heller ikke sagens kerne; de er blot blevet symbolet - eller symptomet, om man vil - på de ofte stærkt følelsesladede modsætninger mellem Kina og Japan.

De to nationer har regionens største økonomier. I fjor overhalede Kina USA og blev Japans største handelspartner. De har en del grunde til at holde sig gode venner - ikke mindst deres samhandel på 170 mia. dollars i fjor - som ventes at stige til 190 mio. i år. Japan er storeksportør til Kina og direkte afhængig af denne eksport til at holde $\varnothing$ konomien i luften. De 1,3 mia. kineseres forbrug stiger eksplosivt ligesom deres eksport til Japan. De to lande er indbyrdes dybt afhængige.

\section{Strukturelle spændinger}

Dette er en oplagt fælles sag, som så martres af begge landes stærkt stigende behov for energi - en direkte følge af omtalte voksende eksport og forbrug. Endnu et alvorligt stridspunkt er da også begge landes krav på naturgasfelter i Det Østkinesiske Hav. I den forbindelse forbeholder Kina sig "retten til yderligere reaktion" på Japans krav.

Taiwan spiller også ind. Kina måtte afstå Taiwan til Japan i 1895. Japan måtte afstå den bananformede $\varnothing$ i Det Kinesiske Hav efter Den Anden Verdenskrig, og der hersker sta- dig nære forbindelser mellem taiwanerne og japanerne. Da Kuomintang led nederlag til kommunisterne på fastlandet i 1949, tog de flugten over Taiwan Strædet og slog sig ned - med bl.a. statskassen og Kinas store kunstskatte.

I mange år fastholdt både Folkerepublikken Kina og nationalistregeringen på Taiwan kravet på regeringsmagten i hele Kina. Det gør Kina stadig, mens Taiwan nu åbenlyst nærer ønske om selvstændighed. I den forbindelse er Taiwan ikke blind for at udnytte forholdet til Japan i den standende strid med fastlandet.

Så er der Japans ønske om et permanent sæde i FN's Sikkerhedsråd. Reformer i FN vil medføre flere faste pladser end de fem nuværende Kina, Rusland, Storbritannien, USA og Frankrig; sejrherrer i Anden Verdenskrig og erklærede atommagter. Anden Verdenskrigs anden store taber, Tyskland, er selvskreven til en plads i et udvidet permanent Sikkerhedsråd, mener Kina, der på det kraftigste modsætter sig Japans optagelse som permanent medlem.

Kina påpeger, at Tyskland har indført love, der skal forhindre enhver form for forsøg på at ændre på historiens dom over nazismen - eller nazi-fascismen, som det hedder i Kina. Japan, derimod, har trykt skolebøger for at rense sit omdømme og slå en streg over tiden som invasionshær og besættelsesmagt, hedder det.

Kina siger, at Japan ganske mang- 
ler de "moralske kvalifikationer," det kræver at have fast plads i Sikkerhedsrådet. Tang Jiaxun, der er medlem af Kinas magtfulde Statsråd og tidligere udenrigsminister, sagde i april, at "allerede i 1970'erne knælede Vesttysklands daværende kansler, Willy Brandt, foran Holocaust Monumentet i Warszawa for at vise sit lands dybe anger. Men Japans ministerpræsident besøger fortsat hvert år Yasukuni-helligdommen. Hvilken kontrast!"

Yasukuni i Tokyo er mindesmærke for Japans faldne under Den Anden Verdenskrig - herunder 14 krigsforbrydere, som blev dømt ved en asiatisk krigsforbryderdomstol efter Den Anden Verdenskrig - og hvert år holdes der mindehøjtidelighed, som ministerpræsidenten deltager i.

"Det kinesiske folk er ude af stand til at begribe, hvordan en nation, der ikke ærligt kan se sin egen historie i øjnene, og som ikke formår at forstå ofrenes følelser i de lande, som landet har forbrudt sig imod, på nogen måde kan kvalificere sig til et fast sæde i FN's Sikkerhedsråd," sagde Tang også. Nok så væsentligt, om end det ikke er blevet sagt i direkte vendinger, er, at Kina ganske enkelt ikke agter at dele Asiens plads i Sikkerhedsrådet med andre.

\section{Historiens spejl}

Under et møde i Beijing i april sagde Japans udenrigsminister, Nobutaka Machimura, til sin kinesiske kollega, Li Zhaoxing, at Japans invasion af Kina i den moderne historie gjorde ubodelig skade over for det kinesiske folk. Og han gentog, at den japanske side inderligt fortryder og undskylder. Erklæringen havde en del til fælles med Tanakas undskyldning over for Mao Zedong. Dengang virkede den nogenlunde. Det gjorde den ikke i år.

Nobutaka Machimura sagde også, at Japans regering vil efterleve ånden $i$ at "se sig i historiens spejl og rette blikket mod fremtiden" og udvikle det japansk-kinesiske venskab med udgangspunkt i de overordnede forbindelser.

Ministerpræsident Wen Jiabao var i Indien, hvor han meddelte, "kun et land, der respekterer historien, tager ansvar for sin fortid og vinder hele Asiens tillid, kan påtage sig et større ansvar i det internationale samfund." For med til historien hører også, at Japan arbejder sig væk fra den ydmygende status som et land, der kun må have selvforsvarsstyrker - i modsætning til et regulært militær. Og bag den vision gemmer sig ønsket om at gøre Kina rangen stridig som regionens stærkeste militærmagt.

Vejen til det - og en i japansk optik genoprejsning efter nederlaget i Anden Verdenskrig - er en større rolle i det internationale samfund. Japan har efterhånden arbejdet sig op til at være blandt verdens største bistandsydere og har stået for langt størsteparten af en række FN-indsat- 
ser, først og fremmest UNTAC, som stiftede fred i Cambodia i begyndelsen af 1990'erne og banede vejen for demokrati (som dog ikke har været i stand til at slå rod, men det er en anden historie).

Singapores premierminister, Lee Hsien Loong, har forsøgt at mægle. Han støtter Japans optagelse i Sikkerhedsrådet, men fraråder den japanske ministerpræsidents årlige besøg i Yasukuni. "Og begge lande bør nedtone deres nationalisme, få løst territorial strid og finde veje til at afdramatisere situationen og gøre en helhjertet indsats for at rette op på den," siger Lee også.

Han mere end antyder, hvor følelsesladet konflikten er. I Japan svarede en kabinetssekretær på regeringens vegne, "at kommentere yderligere ville ikke være konstruktivt for de japansk-kinesiske forbindelser, så jeg vil ikke kommentere."

Kina reagerer skarpt, hver gang Japan ser ud til at styrkes. Hvad er det egentlig Kina vil? Det får vi ikke at vide. Historiens spejl er naturligvis vigtigt. Det er også det mest konkrete krav til Japan fra Kina. Japan stikker den samme undskyldning igen og igen. Kina synes hverken den virker reel eller ærlig.

Man fristes til at tro, at de løbende modsætninger nærmest er ligegyldige. Det stikker dybere og handler om noget andet. Mao Zedong godtog ministerpræsident Tanakas undskyldning dengang i 1972 - og gav dermed også afkald på krigs- skadeerstatning. Dengang skulle normaliseringen ifølge interne dokumenter "bidrage til kampen mod amerikansk og sovjetisk hegemoni, særlig sovjet-revisionismen," der jo bød Mao Zedong så meget imod, at han brød med Nikita Krustjov, da denne forsøgte at pille noget af glorien af Josef Stalin i sidste halvdel af 1950 'erne. Mao Zedong var en stor beundrer af Stalin og tålte ikke efterfølgerens kritik af ham.

På Mao Zedongs geopolitiske vægt vejede en normalisering af forholdet til Japan langt tungere end en revision af Kinas og Japans fælles historie samt en mulig erstatning. Normaliseringen skulle også tjene til at forsinke den militære oprustning, som man måtte formode Japan sigtede imod, og som allerede dengang blev betragtet med bekymring af Kina

En normalisering var der næppe tale om fra kinesisk side i 1972; snarere en overordentlig praktisk foranstaltning. I Kina var Kulturrevolutionens værste excesser overstået, men landet var dog i indre oprør.

\section{Riget i Midten}

Kina har aldrig tilgivet Japan. Kina har været i stand til at skabe fred eller i hvert fald i store træk fredelig sameksistens - hele vejen langs landets grænse. Der hersker tålelige forhold til historiske fjender som Indien, Vietnam og Rusland.

Der findes i Kina en udbredt na- 
tionalisme. Uanset politik og styreform er Kina fortsat Riget i Midten og alle andre lande i princippet vasaller eller mindreværdige. Frem til begyndelsen af det 20. årh. havde Kina ikke noget udenrigsministerium - kun Tsungliyamen, der tog imod tribut. Et ministerium, hvis eneste portefølje var at modtage gaver fra andre lande. I Kinas øjne eksisterede der ikke nogen form for jæunbyrdighed mellem Kina og andre lande. Tanken var kineserne ubegribelig - og er det stadig i den umådelige nationale stoltheds $\mathrm{og}$ fædrelandskærligheds navn.

Kina har aldrig forliget sig med ydmygelserne, der indledtes med nederlagene i Opiumskrigene i 1840'erne. Derfra gik det støt ned ad bakke under enkekejserinde Xicis ukyndige ledelse. Det hedder sig, at Kina tabte krigen mod Japan i 1895 , fordi hun havde brugt penge, der skulle have bygget et flådeforsvar, til at indrette sig i Sommerpaladset i Beijing, Yuanmingyuan.

Japan - og siden andre lande - fik koncessioner og åd sig ind i Kina, og under Anden Verdenskrig gjorde det sig klar til at æde hele Kina. Der har altid eksisteret dyb mistro og simpel misundelse mellem de to lande. Japan rejste sig hurtigt efter Anden Verdenskrig og fik betydelig økonomisk magt. Kina trak sig ind i sig selv og indledte et af verdenshistoriens største samfundseksperimenter.

Med Japans økonomiske svækkel- se i slutningen af det 20. årh. og Kinas vældige økonomiske optur kan Kina sætte sig bedre til rette i sin - i egen optik - fuldt fortjente trone som Riget i Midten og dermed tættest på Himlen med det deraf følgende Himmelske Mandat.

For 25 år siden, da Kina begyndte anden runde i sin åbning mod omverdenen og indførte økonomiske reformer, viste meningsmålinger, at japanerne havde et "overvældende godt" indtryk af Kina og kineserne. Dengang var bondekollektiverne lige opløst, man kunne dårligt skaffe en tomat, man kunne dårligt se forskel på mænd og kvinder, kineserne var urfattige og aldeles fortumlede af 30 års dramatiske politiske eksperimenter. Kina var ingen trussel.

\section{Gensidig skepsis}

I dag har kun ca. halvdelen af japanerne "et godt indtryk af Kina." Det er naturligvis betragteligt, men dog en betydelig nedgang. Japanerne er - parret med egen tilbagegang - bekymrede over Kinas succes. Kineserne ser deres voksende succes som den virkelige grund til, hvad de opfatter som japanernes negative indstilling til Kina.

I Kina er udviklingen tilsvarende. Da landet så småt begyndte at åbne sig, beundrede mange unge kinesere (dvs. dem, der ikke havde erindringer fra Anden Verdenskrig) det moderne og velstående Japan og så det som et forbillede. Men nu ople- 
ver kineserne, at de kan selv.

Kina er fortsat ikke noget oplysningssamfund, og myndighederne kontrollerer i meget høj grad medierne. Internettet er selvfølgelig også kommet til Kina, men der er meget skarp kontrol, de menige kineseres forbindelse ud af landet er beskedne. Naturligvis er der kritiske røster og store frustrationer, men de kommer sjældent til orde. Mens myndighederne stadig godkendte de Japan-fjendtlige demonstrationer i Kina, var det helt i orden offentligt at kalde japanerne for fascister. Få dage senere blev et par "sorte hænder" anholdt, og kritikken forstummede.

De kinesiske magthavere er vant til at udøve denne kontrol. Det er et stort og åbent spørgsmål, hvor længe den kan bevares - i særdeleshed i forbindelse med de udbredte arbejderaktioner, der finder sted over hele landet. Men endnu lader det sig gøre, og så kan kineserne ind i mellem få luft for deres frustrationer.

Vi oplevede tilsvarende, da NATO ved en fejltagelse bombede Kinas ambassade i Beograd. Med et slag var titusindvis af kinesere mobiliseret til hadefulde demonstrationer mod NATO-landenes ambassader; noget tilsvarende skete, da Kina og USA kom på kant. Massemobilisering og siden brat afslutning.

I netop forholdet mellem Japan og Kina er der alle de strukturelle spændinger om gas, historieskriv- ningen, Taiwan, sæde eller ej i FN's Sikkerhedsråd. Oven i det er der nogle nærmest surrealistiske følelsesmæssige spændinger, som kan piskes op til betydelige højder; de har rod i historien, men i høj grad også i de to landes selvopfattelser.

På den led er konflikten nærmest uløselig. Og hvis ikke det var så alvorligt, ville det mest af alt minde om en hanekamp. For hvordan løse en konflikt, som aldrig nogensinde bliver kaldt ved sit rette navn? Der findes ikke noget forum som EU eller NATO, hvor Kina og Japan kunne blive kammeratligt tvunget til at løse deres problemer. Intet tyder på, at Singapores bestræbelser vil bære frugt. Det virker bizart, at to lande, hvis økonomiske forbindelser bliver tættere og tættere, og som helt åbenbart har interesse i samarbejde, ikke kan finde en løsning.

15. august er det præcis 60 år siden, Japan overgav sig i Anden Verdenskrig. I netop dette år er der vel grund til at se sig i Historiens Spejl og komme overens med fortiden. Men i forholdet mellem Kina og Japan virker spejlet nærmest modsat.

\section{Mette Holm er journalist; hun har} beskaftiget sig med Kina $i$ over 25 år og har bl.a. arbejdet for TV-Avisen, DR $P 1$ 's Orientering, Weekendavisen m.fl. Hun har desuden skrevet bøger om Kina og andre asiatiske lande og anliggender. 